\title{
Effect of Herbicides on Microbial Population and Soil Enzymes in Bt Cotton Cultivated Soils
}

\author{
M. Tejashree ${ }^{1 *}$, R. Subhash Reddy ${ }^{1}$ and G. Anuradha ${ }^{2}$ \\ ${ }^{1}$ Department of Agricultural Microbiology and Bioenergy, ${ }^{2}$ Institute of Biotechnology, College \\ of Agriculture, Professor Jayashankar Telagana State Agricultural University, \\ Rajendranagar, Hyderabad 500 030, Telangana, India \\ *Corresponding author
}

\section{A B S T R A C T}

\begin{tabular}{|l|}
\hline Ke y w o r d s \\
$\begin{array}{l}\text { Soil microbial biomass, } \\
\text { Dehydrogenase, Acidic } \\
\text { phosphatase, Alkaline } \\
\text { phosphatase and urease }\end{array}$ \\
\hline Article Info \\
\hline $\begin{array}{l}\text { Accepted: } \\
\text { 24 August } 2018 \\
\text { Available Online: } \\
\text { 10 September } 2018\end{array}$ \\
\hline
\end{tabular}

\section{Introduction}

Cotton is an important fiber crop of global significance and is cultivated in tropical and sub- tropical regions of more than seventy countries in the world over. Major producers of cotton are India, China, USA, Brazil, and Pakistan. These countries contribute about $76 \%$ to the total global cotton production. In past 10 years, India, formerly self-sufficient has become the world's largest producer and second largest exporter of cotton. Presently in 2017-18 the cotton area in India is estimated around 11.3 million hectares. In central zone
India is the largest cotton producing country, covers an area of approximately $36 \%$ area representing about 11.3 million hectares under cotton. It also consumes considerable amount of herbicides and pesticides which are biologically active compounds which may lead to the significant changes in the soil microorganisms. Hence, in this study the herbicides viz., pyrithiobac, pendimethalin and pyrithiobac + quizalofop are sprayed as pre-emergence herbicides and the soil samples were collected at squaring, flowering, boll formation and at harvesting stage. The effects of these chemicals were studied on soil enzymes and microbial populations in soil. The study on the soil enzymes and soil microbial population were least effected by pendimethalin followed by pyrithiobac and least activity was seen in pyrithiobac + quizalofop.

Telangana is the major cotton producing state covering an area of 1.25 lakh hectares. Bt cotton is a genetically modified cotton that has one or two genes of soil bacterium Bacillus thuringiensis (Bt) coding for $\mathrm{Bt}$ toxin insecticide in its tissues. This Bt toxin is specific to lepidopteron pests, and the major pest of cotton i.e. boll worm belonging to lepidopteron groups. It got highly popularized till 2009 entomologists by a group of from Monsanto company and confirmed pink bollworm has developed resistance to $\mathrm{Bt}$ cotton. This leads to increased usage of chemicals to control pests and weeds. 
However, the effect of the Bt toxin on microbial activity in soil (Xiaogang et al., 2011) is yet to be established. They reported that there could be changes in the root secretions important to soil microbes. The addition of the herbicides can cause qualitative and quantitative alterations in soil microbial populations and their soil enzyme activities (Min et al., 2002; Saeki and Toyota, 2004).

Estimation of microbial biomass (Nunan et al., 1998) was also taken into account in this particular research work as microbial biomass was a measure of the mass of the living components of soil organic matter which mostly consists of fungi and bacteria. There is also considerable interest in study of enzymes of soils (Burns, 1978) because such activities may reflect the potential of soil to perform certain biological transformations of importance to soil fertility.

Thus there is a need to study the influence of herbicides on the microflora and their enzyme activities in soil. Apart from this, the present study also helped to compare the soil metabolic activities of $\mathrm{Bt}$ cotton with the non Bt cotton.

\section{Materials and Methods}

The soil samples were collected from black soil in the college farm, PJTSAU, Rajendranagar for this experiment. The soil samples were collected from nonBt cotton and $\mathrm{Bt}$ cotton at four stages i.e.at squaring stage, flowering stage, boll formation stage and harvesting stage.

\section{Sterilization of glassware and media}

Glassware like pipettes was sterilized in the hot air oven at $160^{\circ} \mathrm{C}$ for $1112 \mathrm{~h}$ before use. Petriplates, test tubes with saline and media were used in experiment to estimate the microbial counts. The media like Yeast
Extract Mannitol Agar, Azotobacter Glucose Agar Medium, Plate Count Agar etc. and distilled water were sterilized in an autoclave at $15 \mathrm{lb}$ psi $\left(121^{\circ} \mathrm{C}\right)$ for $20 \mathrm{~min}$.

\section{Preparation of media}

\section{Potato dextrose agar}

Potato dextrose agar medium (Himedia) was used for the isolation of total fungi population from rhizosphere soil of cotton to take counts. To prepare media $39.0 \mathrm{~g}$ of PDA is taken and dissolved in $1000 \mathrm{ml}$ of distilled water and sterilized in an autoclave at $15 \mathrm{psi}\left(121^{\circ} \mathrm{C}\right)$ for $15 \mathrm{~min}$.

\section{Kings' B media}

Kings' B medium was prepared by taking $20 \mathrm{~g}$ proteose peptone, $1.5 \mathrm{~g}$ of $\mathrm{K}_{2} \mathrm{HPO}_{4}, 1.5 \mathrm{~g}$ of $\mathrm{MgSO}_{4} .7 \mathrm{H}_{2} \mathrm{O}$ and $15 \mathrm{~g}$ of agar agar in $1000 \mathrm{ml}$ of distilled water and sterilized in an autoclave at $15 \mathrm{psi}\left(121^{\circ} \mathrm{C}\right)$ for $15 \mathrm{~min}$.

\section{Azotobacter glucose medium}

Azotobacter glucose medium (Himedia) was prepared by taking $31.48 \mathrm{~g}$ of the Azotobacter glucose medium and mixed in $1000 \mathrm{ml}$ of distilled water and sterilized in an autoclave at $15 \mathrm{psi}\left(121^{\circ} \mathrm{C}\right)$ for $15 \mathrm{~min}$.

\section{Azospirillum medium}

Azospirillum medium was prepared by taking $6.33 \mathrm{~g}$ of the Azospirillum medium part A and mixing in $1000 \mathrm{ml}$ of distilled water and sterilized in an autoclave at $15 \mathrm{psi}\left(121^{\circ} \mathrm{C}\right)$ for 15 min. After autoclaving $4.0 \mathrm{~g}$ of Azospirillum medium part $\mathrm{B}$ is dissolved in $50 \mathrm{ml}$ of distilled water. Sterilized part A Azospirillum medium is mixed with Azospirillum part $\mathrm{B}$ and finally it is seen that the $\mathrm{pH}$ is set around 7.0 with the help of $\mathrm{pH}$ paper. 


\section{Rhizobium medium}

Rhizobium medium was prepared by taking 31.83g Yeast Extract Mannitol with Congo Red medium (Himedia) and dissolving in $1000 \mathrm{ml}$ of water and sterilized in an autoclave at $15 \mathrm{psi}\left(121^{\circ} \mathrm{C}\right)$ for $15 \mathrm{~min}$.

\section{Plate count agar}

It is prepared by taking $25.5 \mathrm{~g}$ of PCA (Himedia) and it was dissolved in $1000 \mathrm{ml}$ of distilled water and sterilized in an autoclave at $15 \mathrm{psi}\left(121^{\circ} \mathrm{C}\right)$ for $15 \mathrm{~min}$.

\section{Starch casein agar}

It is used to take the actinomycetes counts in the soil sample. Medium is prepared by taking $63.0 \mathrm{~g}$ of the SCA (Himedia) and dissolved it in $1000 \mathrm{ml}$ of distilled water and sterilized in an autoclave at $15 \mathrm{psi}\left(121^{\circ} \mathrm{C}\right)$ for $15 \mathrm{~min}$.

\section{Soil Enzymes}

Dehydrogenase enzyme was described by Casida et al., (1964), acid phosphatases by Tabatabai and Bremner (1969), alkaline phosphatases by Eivazi and Tabatabai (1977), and urease enzyme was determined as described by Tabatabai and Bremner (1972). The herbicide treatments were compared with Bt cotton without any herbicide treatment and $\mathrm{Bt}$ cotton in turn compared with the non $\mathrm{Bt}$ cotton to know the effect of the transgenic crops on metabolic activities in the soil.

\section{Results and Discussion}

Microbial counts in the soil samples

\section{Stage I - Squaring Stage}

The microbial counts of Rhizobium, Azotobacter, Azospirillum, Pseudomonas, actinomycetes, bacteria, and fungi were taken at squaring in $\mathrm{Bt}$ and non $\mathrm{Bt}$ cotton are presented in the figure 1.

The Bt cotton with herbicide treatments when compared with the non Bt cotton, microbial counts of Azospirillum, actinomycetes, fungi and VAM were on a par with each other, whereas counts of Rhizobium $\left(14.67 \times 10^{3} \mathrm{CFU} / \mathrm{g}\right.$ of soil), Azotobacter $\left(4 \times 10^{3}\right.$

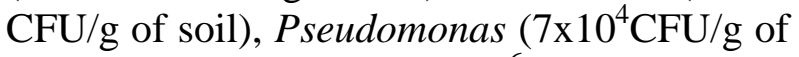
soil) and bacteria $\left(24.33 \times 10^{6} \mathrm{CFU} / \mathrm{g}\right.$ of soil $)$ were recorded significantly more in Non-Bt cotton. Among the Bt cotton with herbicide treatments, the counts of Azospirillum ( $4 \times 10^{3}$ $\mathrm{CFU} / \mathrm{g}$ of soil) and actinomycetes $\left(5 \times 10^{5}\right.$ $\mathrm{CFU} / \mathrm{g}$ of soil) and fungi (9x $10^{3} \mathrm{CFU} / \mathrm{g}$ of soil) were found high in the treatment $\mathrm{Bt}$ cotton + pendimethalin. Lowest counts of all microbes were found in the treatment $\mathrm{Bt}$ cotton + pyrithiobac sodium + quizalofop (Table 1). Compared to non Bt cotton soil, microbial population in remaining Bt cotton treatments all microbial groups were found significantly low.

\section{Stage II - Flowering stage}

All the microbial counts of Rhizobium, Azotobacter, Azospirillum, Pseudomonas, actinomycetes, bacteria, fungi and VAM were estimated at flowering stage in Bt and non Bt cotton are shown in the figure 2 .

The microbial counts of Non-Bt cotton when compared to the Bt cotton significantly high counts were obtained for Rhizobium, Azotobacter, Pseudomonas, bacteria and fungi whereas Azospirillum, Actinomycetes and VAM were found on a par in both the treatments.

Microbial counts in Bt cotton when compared with $\mathrm{Bt}$ cotton + herbicide treatments, highest counts of bacteria $\left(32.33 \times 10^{3} \mathrm{CFU} / \mathrm{g}\right.$ of soil) were found in $\mathrm{Bt}$ cotton whereas highest

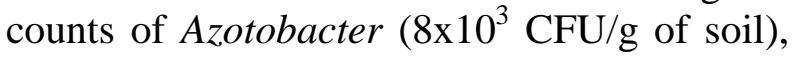


Pseudomonas $\left(11.33 \times 10^{4} \mathrm{CFU} / \mathrm{g}\right.$ of soil), actinomycetes $\left(10 \times 10^{5} \mathrm{CFU} / \mathrm{g}\right.$ of soil) and fungi $\left(11.33 \times 10^{3} \mathrm{CFU} / \mathrm{g}\right.$ of soil) were found in the treatment $\mathrm{Bt}$ cotton + pendimethalin. Themicrobial count of Rhizobium was on a par with each other and Azospirillum $\left(7 \times 10^{3}\right.$ $\mathrm{CFU} / \mathrm{g}$ of soil) was found same in $\mathrm{Bt}$ cotton and $\mathrm{Bt}$ cotton + pendimethalin treatment. Significantly lower microbial counts among all treatments were observed in treatment $\mathrm{Bt}$ cotton + pyrithiobac sodium + quizalofop (Table 2).

\section{Stage III - Boll formation}

The microbial counts of Rhizobium, Azotobacter, Azospirillum, Pseudomonas, actinomycetes, bacteria, and fungi were taken at boll formation stage in Bt and non Bt cotton are shown in figure 3. All the microbial counts were found significantly high in Non-Bt cotton when compared with $\mathrm{Bt}$ cotton (Table $3)$.

Microbial counts of the $\mathrm{Bt}$ cotton and $\mathrm{Bt}$ cotton with herbicide treatments when compared, highest counts of Rhizobium $\left(17.33 \times 10^{3} \mathrm{CFU} / \mathrm{g}\right.$ of soil), Azotobacter $\left(11.66 \times 10^{3} \quad \mathrm{CFU} / \mathrm{g}\right.$ of soil), bacteria (36.67 $\times 10^{6} \mathrm{CFU} / \mathrm{g}$ of soil) and fungi $\left(10 \times 10^{3}\right.$ $\mathrm{CFU} / \mathrm{g}$ of soil)were found in $\mathrm{Bt}$ cotton whereas the counts of Pseudomonas $\left(13 \times 10^{4}\right.$ CFU/g of soil) and actinomycetes $\left(7 \times 10^{5}\right.$ CFU/g of soil) were found high in the treatment $\mathrm{Bt}$ cotton + pendimethalin. The microbial count of Azospirillum (9x $10^{3} \mathrm{CFU} / \mathrm{g}$ of soil) was found same in $\mathrm{Bt}$ cotton and $\mathrm{Bt}$ cotton + pendimethalin. Among the herbicide treatments significantly more number of microbial counts were observed in Bt cotton + Pendimethalin when compared to two treatments i.e., Bt cotton soil + Pyrithiobac sodium and $\mathrm{Bt}$ cotton + pyrithiobac sodium + quizalofop. Significantly lower microbial counts were found in the treatment Bt cotton + pyrithiobac sodium + quizalofop (Table 3 ).

\section{Stage IV - Harvesting stage}

The microbial counts Rhizobium, Azotobacter, Azospirillum, Pseudomonas, actinomycetes, bacteria, and fungi were taken in Bt cotton and non Bt cotton soil samples collected at harvesting stage are shown in figure 4 .

All the microbial counts were found significantly high in Non-Bt cotton when compared with Bt cotton (Table 4).

Microbial counts in Bt cotton grown soil when compared with herbicide treated soils, significantly higher counts of Azotobacter $\left(8 \times 10^{3} \mathrm{CFU} / \mathrm{g}\right.$ of soil $)$, bacteria $\left(29.67 \times 10^{6}\right.$ $\mathrm{CFU} / \mathrm{g}$ of soil) were observed in soil grown with Bt cotton and the microbial counts of Pseudomonas $\left(12.67 \times 10^{4} \mathrm{CFU} / \mathrm{g}\right.$ of soil), Azospirillum $\left(5.33 \times 10^{3} \quad \mathrm{CFU} / \mathrm{g}\right.$ of soil), Rhizobium $\left(9.67 \times 10^{3} \quad \mathrm{CFU} / \mathrm{g}\right.$ of soil), actinomycetes $\left(4 \times 10^{5} \mathrm{CFU} / \mathrm{g}\right.$ of soil) and fungi $\left(7 \times 10^{3} \mathrm{CFU} / \mathrm{g}\right.$ of soil) were observed in treatment Bt cotton + pendimethalin.

Significantly high microbial counts were observed in Bt cotton + Pendimethalin when compared to the other two Bt cotton herbicide treatments i.e. $\mathrm{Bt}$ cotton soil + Pyrithiobac sodium and Bt cotton + pyrithiobac sodium + quizalofop (Table 4).

All the microbes showed a decrease their population immediately after the application of herbicide as it may have toxic effect on them (Bowels et al., (2014). Later microorganisms decompose herbicides Jarvan et al., (2014) and they may serve as biogenic indicators elements for their own physiological process as reported by Bera and Ghosh (2013).

Significant decrease in microbial counts of Azotobacter was due to the application of herbicide (Nada et al., 2002) and actinomycetes (Hang et al., 2001). 
Table.1 Microbial counts in soils collected at squaring in Non Bt and Bt cotton, college farm, Rajendranagar (CFU/g of soil)

\begin{tabular}{|c|c|c|c|c|c|c|c|c|}
\hline Treatment & $\begin{array}{c}\text { Rhizobium } \\
\times 10^{3}\end{array}$ & $\begin{array}{c}\text { Azotobacter } \\
\times 10^{3}\end{array}$ & $\begin{array}{c}\text { Azospirillum } \\
\times 10^{3} \\
\end{array}$ & $\begin{array}{l}\text { Pseudomonas } \\
\mathbf{x} 10^{4}\end{array}$ & $\begin{array}{l}\text { Actinomycetes } \\
\qquad \times 10^{5}\end{array}$ & $\begin{array}{c}\text { Bacteria } \\
\times 10^{6}\end{array}$ & $\begin{array}{l}\text { Fungi } \\
\times 10^{3}\end{array}$ & $\begin{array}{l}\text { VAM } \\
\mathbf{x} 10\end{array}$ \\
\hline T1(N.Bt) & 14.67 & 9 & 4 & 12.67 & 3.83 & 31.33 & 10.33 & 10.93 \\
\hline T2(Bt) & 8.33 & 3 & 3.17 & 7 & 3 & 24.33 & 7 & 9.87 \\
\hline T3(Bt+pyrithiobac) & 7.33 & 3 & 3 & 3 & 4 & 21 & 7.67 & 8.63 \\
\hline T4(Bt+Pendimethalin) & 8 & 4 & 4 & 4 & 5 & 21.67 & 9 & 9.27 \\
\hline T5(Bt+pyri+quizalofop) & 7 & 2.17 & 3 & 6 & 3 & 20.67 & 5.33 & 8.33 \\
\hline $\mathrm{SE}(\mathrm{m})$ & 0.05 & 0.06 & 0.06 & 0.13 & 0.06 & 0.28 & 0.22 & 0.58 \\
\hline
\end{tabular}

Table.2 Microbial counts in soil collected at flowering in Non Bt and Bt cotton from college farm, Rajendranagar (CFU/g of soil)

\begin{tabular}{|c|c|c|c|c|c|c|c|c|}
\hline Treatment & $\begin{array}{c}\text { Rhizobium } \\
\times 10^{3}\end{array}$ & $\begin{array}{c}\text { Azotobacter } \\
\mathbf{x} 10^{3}\end{array}$ & $\begin{array}{c}\text { Azospirillum } \\
\times 10^{3}\end{array}$ & $\begin{array}{c}\text { Pseudomonas } \\
\times 10^{4}\end{array}$ & $\begin{array}{l}\text { Actinomycetes } \\
\times 10^{5}\end{array}$ & $\begin{array}{c}\text { Bacteria } \\
\times 10^{6}\end{array}$ & $\begin{array}{l}\text { Fungi } \\
\times 10^{3}\end{array}$ & VAM x10 \\
\hline T1(N.Bt) & 18.67 & 14 & 8 & 15 & 6 & 40.67 & 12 & 11.73 \\
\hline T2(Bt) & 11.67 & 5 & 7 & 8.33 & 4 & 32.33 & 8 & 10.07 \\
\hline T3(Bt+pyrithiobac) & 10 & 5.33 & 5 & 9 & 7 & 27.33 & 9.67 & 9.33 \\
\hline T4(Bt+Pendimethalin) & 11.33 & 8 & 7 & 11.33 & 10 & 30 & 11.33 & 10.27 \\
\hline T5(Bt+pyri+quizalofop) & 9.67 & 4 & 4.33 & 7 & 5.17 & 25 & 8.33 & 9.17 \\
\hline SE(m) & 0.25 & 0.13 & 0.13 & 0.18 & 0.06 & 0.33 & 0.22 & 0.49 \\
\hline CD 5\% & 0.76 & 0.38 & 0.38 & 0.54 & 0.19 & 1.01 & 0.66 & 1.48 \\
\hline
\end{tabular}

Table.3 Microbial counts in soils collected at boll formation in Non Bt and Bt cotton from college farm, Rajendranagar (CFU/g of soil)

\begin{tabular}{|c|c|c|c|c|c|c|c|c|}
\hline Treatment & $\begin{array}{c}\text { Rhizobium } \\
\times 10^{3}\end{array}$ & $\begin{array}{l}\text { Azotobacter } \\
\times 10^{3}\end{array}$ & $\begin{array}{c}\text { Azospirillum } \\
\times 10^{3}\end{array}$ & $\begin{array}{c}\text { Pseudomonas } \\
\times 10^{4}\end{array}$ & $\begin{array}{l}\text { Actinomycetes } \\
\qquad \times 10^{5}\end{array}$ & $\begin{array}{c}\text { Bacteria } \\
\times 10^{6}\end{array}$ & $\begin{array}{l}\text { Fungi } \\
\times 10^{3}\end{array}$ & VAM x10 \\
\hline T1(N.Bt) & 23.33 & 18.67 & 11.33 & 18 & 8 & 43.33 & 15 & 12.67 \\
\hline $\mathrm{T2}(\mathrm{Bt})$ & 17.33 & 11.67 & 9 & 12.67 & 4 & 36.67 & 10 & 11.93 \\
\hline T3(Bt+pyrithiobac) & 13.33 & 7 & 7 & 8 & 5 & 21.33 & 8 & 10.77 \\
\hline T4(Bt+Pendimethalin) & 16.33 & 9 & 9 & 13 & 7 & 31.33 & 7 & 11.43 \\
\hline T5(Bt+pyri+quizalofop) & 10.67 & 6 & 5 & 6 & 2.67 & 19.67 & 4.33 & 10.33 \\
\hline $\mathrm{SE}(\mathrm{m})$ & 0.33 & 0.22 & 0.18 & 0.13 & 0.13 & 0.44 & 0.18 & 0.31 \\
\hline CD 5\% & 0.01 & 0.66 & 0.05 & 0.38 & 3.38 & 1.32 & 0.54 & 0.94 \\
\hline
\end{tabular}


Table.4 Microbial counts in soils collected at harvesting stage in Non Bt and Btcotton from college farm, Rajendranagar (CFU/g of soil)

\begin{tabular}{|c|c|c|c|c|c|c|c|c|}
\hline Treatment & $\begin{array}{l}\text { Rhizobium } \\
\times 10^{3}\end{array}$ & $\begin{array}{c}\text { Azotobacter } \\
\times 10^{3}\end{array}$ & $\begin{array}{c}\text { Azospirillum } \\
\times 10^{3}\end{array}$ & $\begin{array}{l}\text { Pseudomonas } \\
\times 10^{4}\end{array}$ & $\begin{array}{l}\text { Actinomycetes } \\
\times 10^{5}\end{array}$ & $\begin{array}{c}\text { Bacteria } \\
\times 10^{6}\end{array}$ & $\begin{array}{l}\text { Fungi } \\
\times 10^{3}\end{array}$ & $\begin{array}{c}\text { VAM } \\
\mathbf{x 1 0}\end{array}$ \\
\hline T1(N.Bt) & 17 & 12 & 5 & 18 & 5 & 32.67 & 9.67 & 14.57 \\
\hline T2(Bt) & 9 & 8 & 3 & 11.67 & 2 & 29.67 & 6 & 13.73 \\
\hline T3(Bt+pyrithiobac) & 8 & 3 & 4 & 8 & 3 & 19.33 & 5 & 11.93 \\
\hline T4(Bt+Pendimethalin) & 9.67 & 5 & 5.33 & 12.67 & 4 & 25.33 & 7 & 12.43 \\
\hline T5(Bt+pyri+quizalofop) & 5.67 & 2 & 2 & 6 & 1.83 & 15.33 & 3 & 11.27 \\
\hline $\mathrm{SE}(\mathbf{m})$ & 0.18 & 0.13 & 0.13 & 0.18 & 0.06 & 0.33 & 0.18 & 0.45 \\
\hline CD 5\% & 0.54 & 0.38 & 0.38 & 0.54 & 0.19 & 1.01 & 0.54 & 1.38 \\
\hline
\end{tabular}

Fig.1 Microbial counts in soils collected at squaring in Non Bt and Bt cotton, college farm, Rajendranagar (CFU/g of soil)

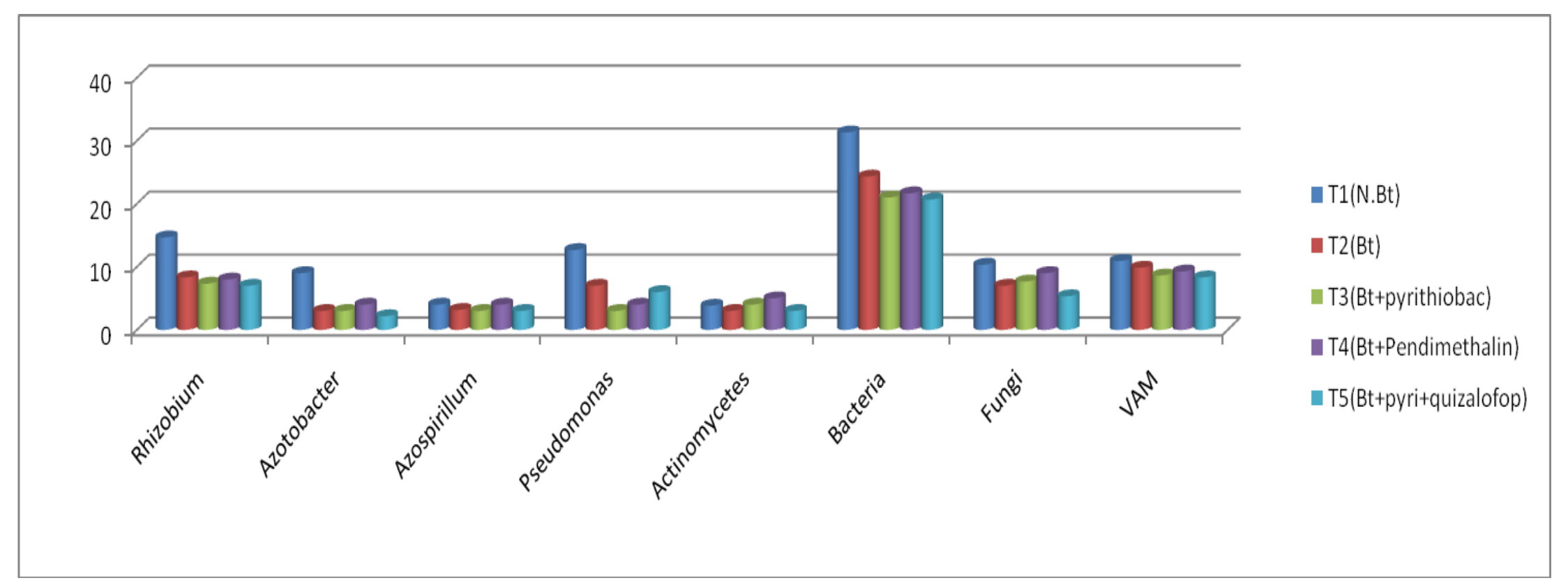


Fig.2 Microbial counts in soil collected at flowering in Non Bt and Bt cotton from college farm, Rajendranagar (CFU/g of soil)

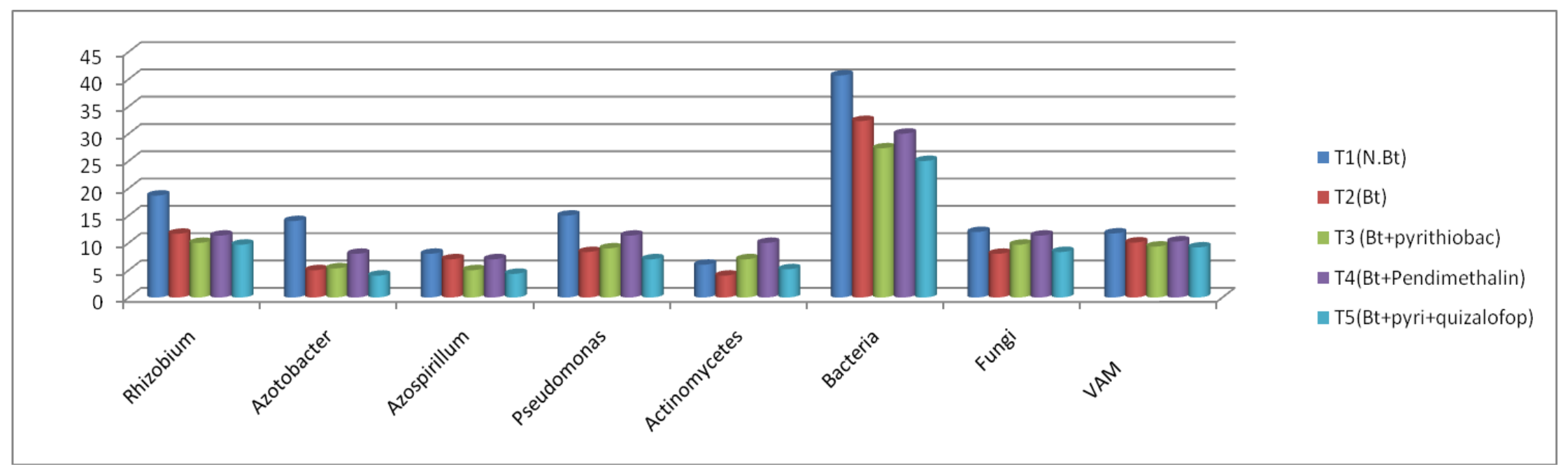

Fig.3 Microbial counts in soils collected at boll formation in Non Bt and Bt cotton from college farm, Rajendranagar (CFU/g of soil)

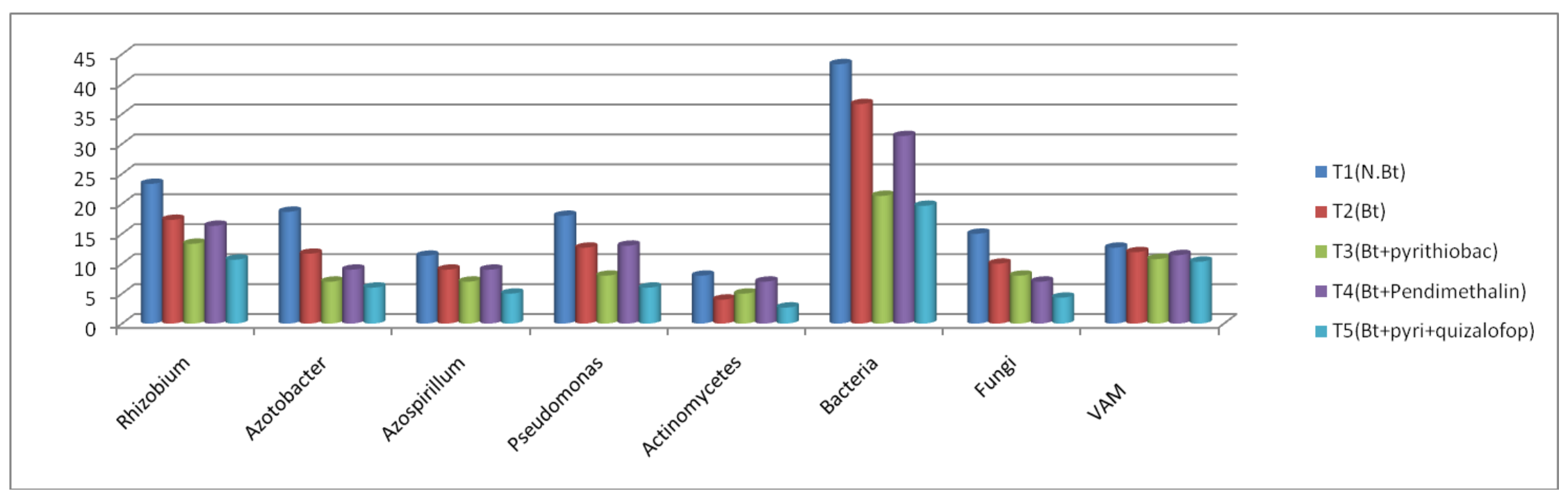


Fig.4 Microbial counts in soils collected at harvesting stage in Non Bt and Bt cotton from college farm, Rajendranagar (CFU/g of soil)

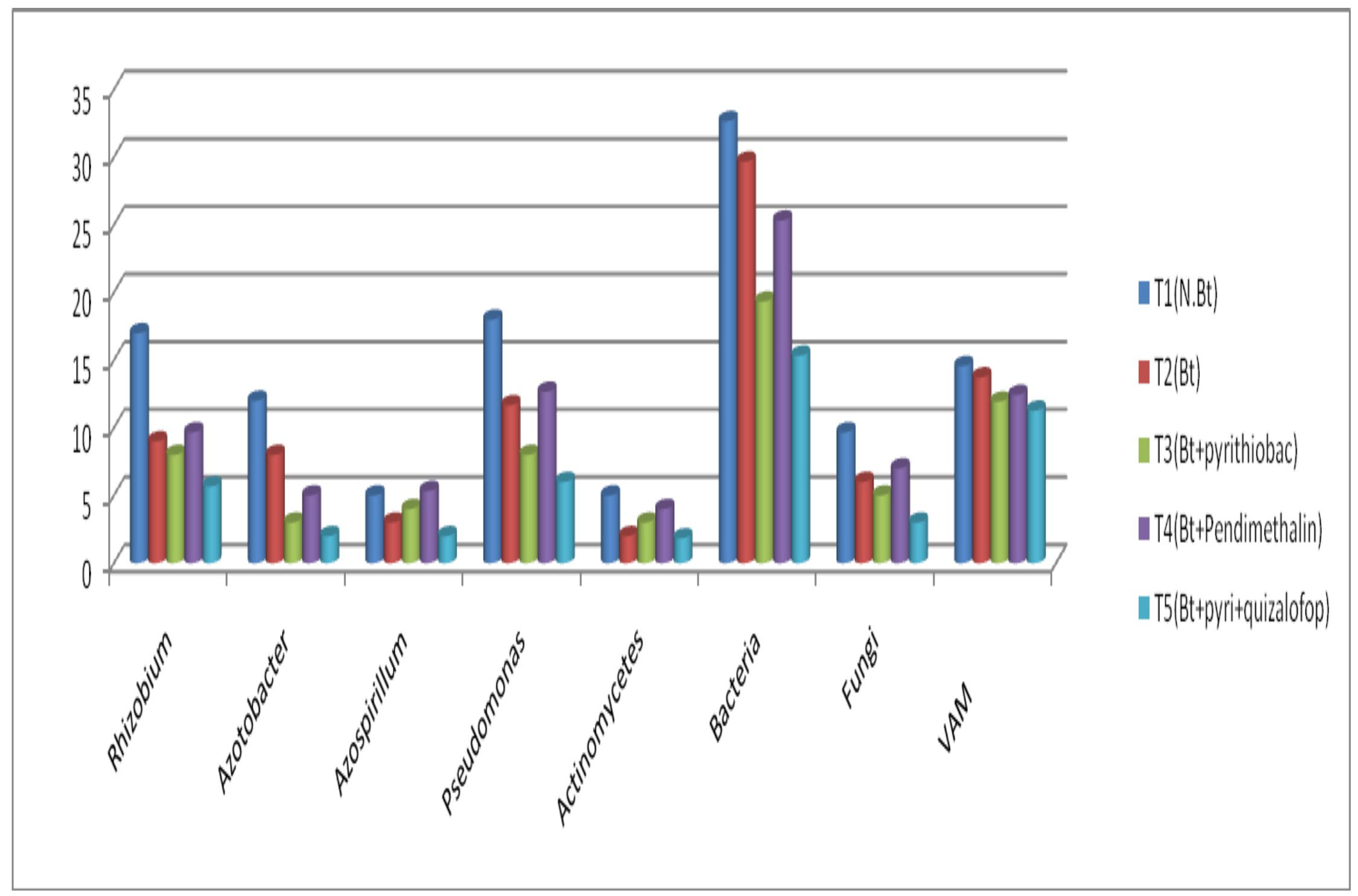


Table.5 Dehydrogenase activity in soils collected at different stages of Non Bt and Bt cotton at from college farm, Rajendranagar ( $\mu \mathrm{g}$ of TPF /g of soil /day)

\begin{tabular}{|c|}
\hline Treatment \\
\hline T1(N.Bt) \\
\hline T2(Bt) \\
\hline T3(Bt+pyrithiobac) \\
\hline T4(Bt+Pendimethalin) \\
\hline T5(Bt+pyri+quizalofop) \\
\hline SE(m) \\
\hline CD 5\% \\
\hline
\end{tabular}

\begin{tabular}{|c|c|c|c|}
\hline Vegetative & Flowering & Boll formation & Harvesting \\
\hline 103.33 & 190 & 200 & 101.67 \\
\hline 80 & 148.33 & 93.33 & 70 \\
\hline 93.33 & 96.67 & 60 & 50 \\
\hline 103.33 & 110 & 73.33 & 58.33 \\
\hline 76.67 & 78.33 & 53.33 & 36.67 \\
\hline 2.44 & 1.67 & 2.27 & 1.99 \\
\hline 7.4 & 5.06 & 6.9 & 6.04 \\
\hline
\end{tabular}

Table.6 Acidic phosphatase activity in soils collected at different stages of Non Bt and Bt cotton at from college farm, Rajendranagar ( $\mu \mathrm{g}$ p-nitrophenol/g/h)

\begin{tabular}{|c|}
\hline Treatment \\
\hline T1(N.Bt) \\
\hline T2(Bt) \\
\hline T3(Bt+pyrithiobac) \\
\hline T4(Bt+Pendimethalin) \\
\hline T5(Bt+pyri+quizalofop) \\
\hline SE(m) \\
\hline CD 5\% \\
\hline
\end{tabular}

\begin{tabular}{|c|c|c|c|}
\hline Vegetative & Flowering & Boll formation & Harvesting \\
\hline 40 & 50 & 38.33 & 20 \\
\hline 28 & 29.67 & 25 & 19.67 \\
\hline 15 & 25.33 & 20.33 & 14.67 \\
\hline 25 & 29.67 & 24.33 & 20 \\
\hline 14.67 & 18.33 & 12 & 10.67 \\
\hline 0.64 & 0.68 & 0.66 & 0.33 \\
\hline 1.95 & 2.06 & 1.99 & 1.01 \\
\hline
\end{tabular}

Table.7 Alkaline phosphatase in soils collected at different stages of Non Bt and Bt cotton at from college farm, Rajendranagar ( $\mu$ g-nitrophenol/g/h)

\begin{tabular}{|c|}
\hline Treatment \\
\hline T1(N.Bt) \\
\hline T2(Bt) \\
\hline T4(Bt+pyrithiobac) \\
\hline T5(Bt+Pendimethalin) \\
\hline T6(Bt+pyri+quizalofop) \\
\hline SE(m) \\
\hline CD 5\% \\
\hline
\end{tabular}

\begin{tabular}{|c|c|c|c|}
\hline Vegetative & Flowering & Boll formation & Harvesting \\
\hline 24.67 & 31.67 & 39.67 & 29.67 \\
\hline 20 & 29.33 & 30.33 & 20.67 \\
\hline 16.67 & 24.67 & 30 & 18.33 \\
\hline 19.67 & 29.67 & 39.67 & 25 \\
\hline 14.67 & 20 & 24.67 & 15 \\
\hline 0.67 & 0.68 & 0.06 & 0.66 \\
\hline 2.02 & 2.06 & 1.71 & 1.99 \\
\hline
\end{tabular}


Table.8 Urease activity in soils in soils collected at different stages of Non Bt and Bt cotton at from college farm, Rajendranagar ( $\mathrm{g}$ of ammonia/gm)

\begin{tabular}{|c|c|c|c|c|}
\hline Treatment & Vegetative & Flowering & Boll formation & Harvesting \\
\hline T1(N.Bt) & 2.07 & 3.03 & 3.43 & 2.43 \\
\hline T2(Bt) & 1.07 & 1.60 & 2.0 & 1.0 \\
\hline T3(Bt+pyrithiobac) & 2.23 & 2.37 & 2.40 & 1.47 \\
\hline T4(Bt+Pendimethalin) & 2.50 & 2.67 & 2.70 & 2.0 \\
\hline T5(Bt+pyri+quivalofop) & 2.0 & 2.23 & 2.30 & 1.03 \\
\hline SE(m) & 0.03 & 0.03 & 0.07 & 0.03 \\
\hline CD 5\% & 0.08 & 0.1 & 0.2 & 0.09 \\
\hline
\end{tabular}

Fig.5 Dehydrogenase activity in soils collected at different stages of Non Bt and Bt cotton at from college farm, Rajendranagar ( $\mu \mathrm{g}$ of TPF /g of soil /day)

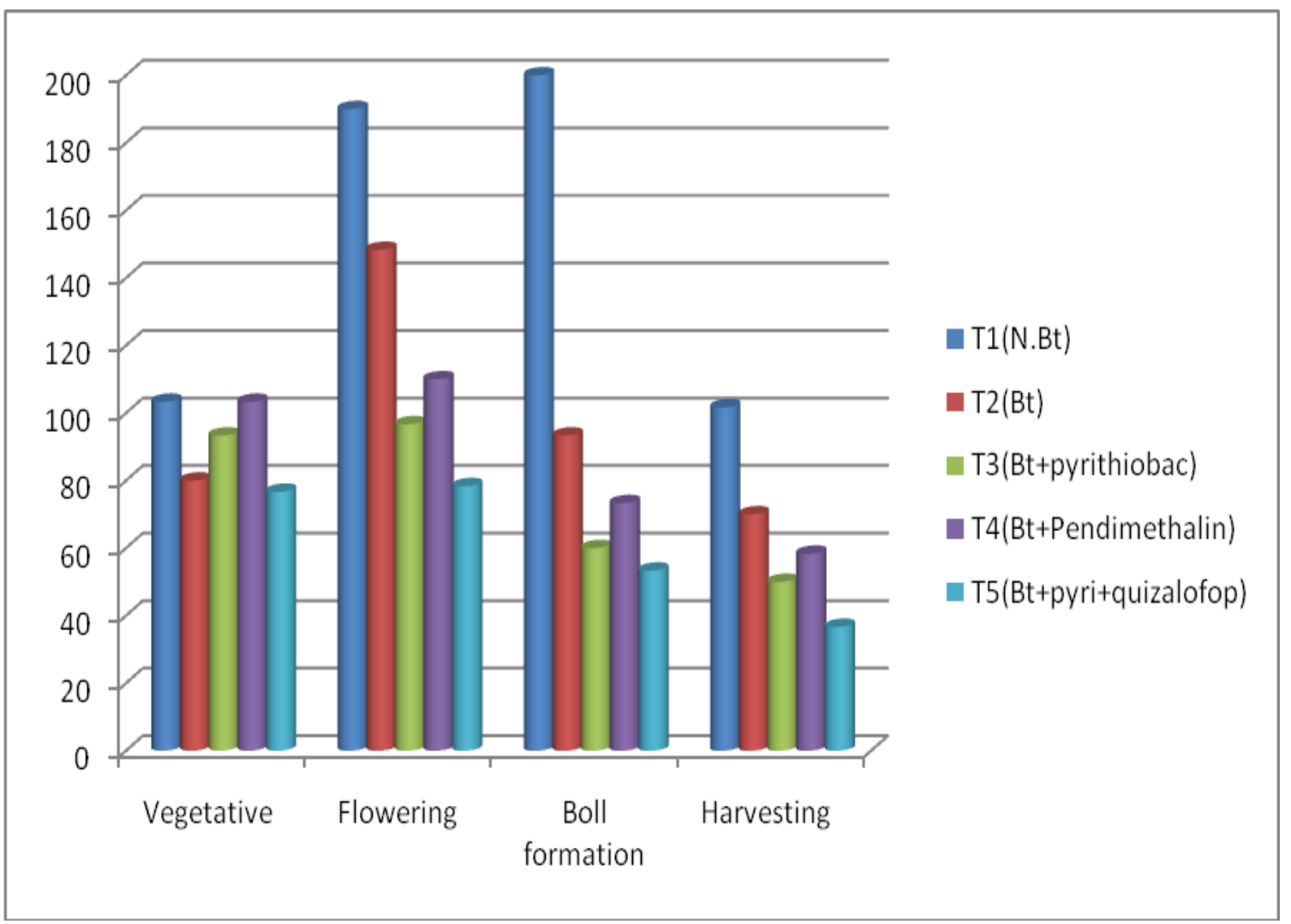


Fig.6 Acidic phosphatase activity in soils collected at different stages of Non Bt and Bt cotton at from college farm, Rajendranagar ( $\mu \mathrm{g}$ p-nitrophenol/g/h)

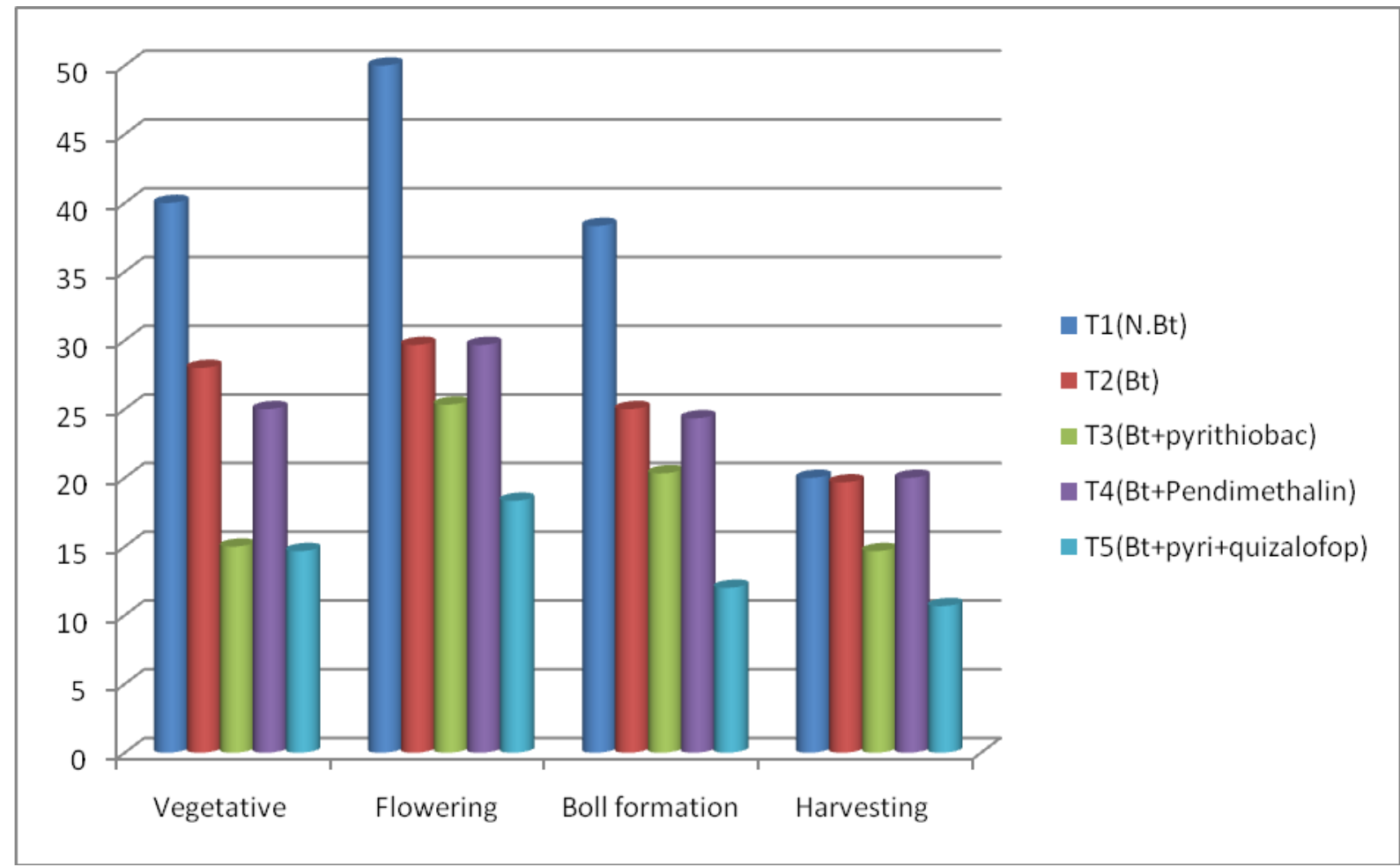

Fig.7 Alkaline phosphatase in soils collected at different stages of Non Bt and Bt cotton at from college farm, Rajendranagar ( $\mu$ g-nitrophenol/g/h)

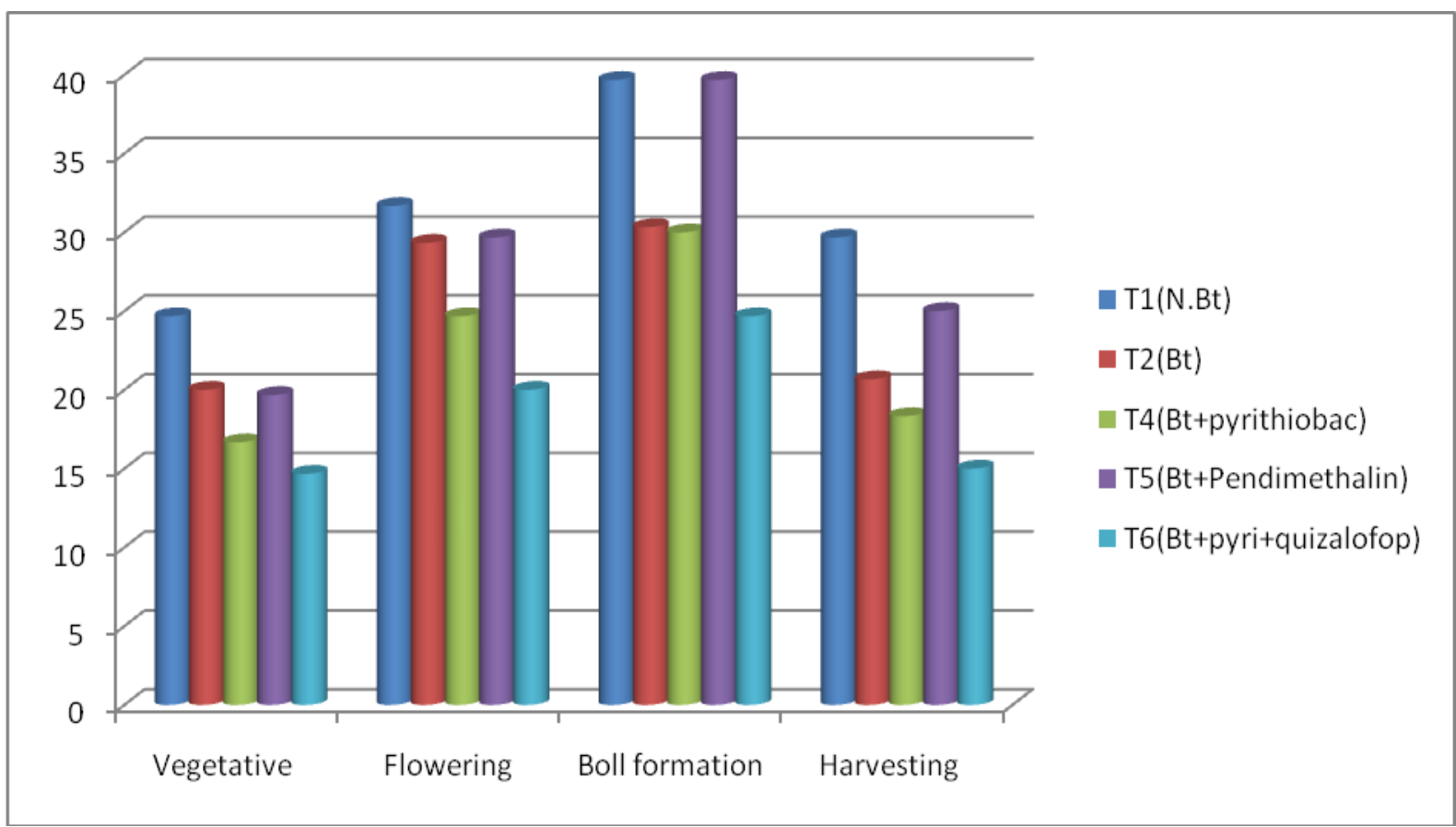


Fig.8 Urease activity in soils in soils collected at different stages of Non Bt and Bt cotton at from college farm, Rajendranagar (g of ammonia/gm)

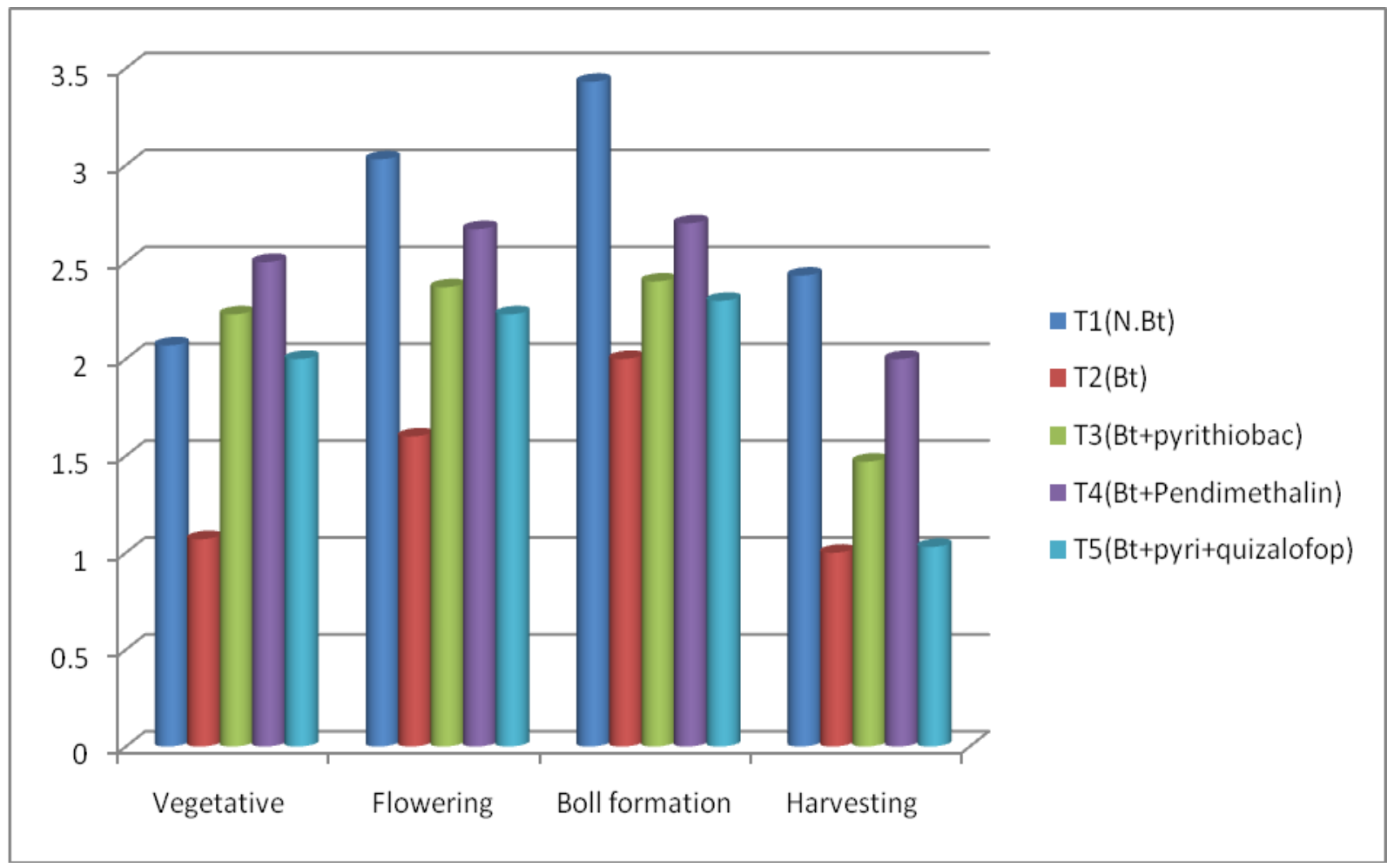

It was often assumed that less than $0.3 \%$ of the herbicides/ pesticides reach the target weed/pest and remaining $99.7 \%$ was released into the environment, representing a potential hazard of non-target organisms (Munoz et al., 2011). Chauhan et al., (2006) reported that herbicides may have toxic effect on soil fungal population up to 20 days of application.

The present study showed increase in microbial population in later stages was in accordance with the study done by Hang et al., (2001) who reported that an increase in bacteria and fungi after the application of herbicides whereas $\mathrm{Tu}$ (1992) reported that there was no effect of herbicides on the soil microorganisms. Anderson (2003) reported that herbicides generally herbicides do not show adverse effect on total bacterial population in soil except at concentrations exceeding recommended rates.
Nada et al., (2002) concluded that number of actinomycetes and fungi increased due to application of the herbicides indicating that these microorganisms used herbicides as a source of biogenous elements. Veena et al., (2010) reported that few bacteria and fungi Atri et al., (2006) in the soil which are able to degrade the herbicide and use these end products as sole source of carbon and accumulated metabolites are used as carbon as well as energy source. This might be the reason for high microbial biomass and microbial counts in the $\mathrm{Bt}$ cotton + Pendimethalin treatment.

\section{Soil enzymes}

\section{Dehydrogenase enzyme activity (DHA)}

Dehydrogenase enzyme activity in Non Bt cotton soil when compared with Bt cotton soil, Non Bt cotton was found to have the 
significantly higher amount of dehydrogenase activity at all growth stages. Highest DHA was found $(200 \mu \mathrm{g}$ of $\mathrm{TPF} / \mathrm{g}$ of soil/day) at boll formation stage in non $\mathrm{Bt}$ cotton grown soil whereas lowest DHA was found in $\mathrm{Bt}$ cotton $(70 \mu \mathrm{g}$ of $\mathrm{TPF} / \mathrm{g}$ of soil/day) at harvesting stage. Considerably high DHA was recorded in $\mathrm{Bt}$ cotton when compared with $\mathrm{Bt}$ cotton + herbicide treatments at all growth stages. High DHA was found in Bt cotton (148.33 $\mu \mathrm{g}$ of $\mathrm{TPF} / \mathrm{g}$ of soil/day) followed by $\mathrm{Bt}$ cotton with pendimethalin treatment

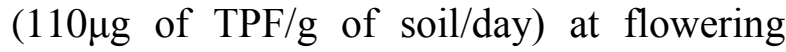
stage. At harvesting stage all the treatments found to have the low DHA except in $\mathrm{Bt}$ cotton soil without any herbicide treatment. The treatment Bt cotton + pyrithiobac sodium + quizalofop (T5) was found to have lowest DHA (41.3 $\mu \mathrm{g}$ of $\mathrm{TPF} / \mathrm{g}$ of soil/day) was recorded at harvesting stage. DHA was observed to increase till boll formation stage and decreased at harvesting stage in all the treatments (Table 5). Significant decrease in DHA was observed when non Bt cotton was compared with the $\mathrm{Bt}$ cotton grown soil shown in figure 5.

Dehydrogenase activity reflects the oxidative activity or intensity of the metabolism of soil micro flora and can be used as an indicator of microbial activity or populations in soils (Nannipieri et al., 2003). Gu et al., (2011) reported that among the enzymes in the soil environment, dehydrogenases (DHA) are one of the most important and used as an indicator of overall soil microbial activity. High DHA was recorded in non $\mathrm{Bt}$ cotton indicating the high microbial activity in the soil, as these enzyme do not accumulate in soil and acts as direct indicator of the soil microbial activity.

Chu et al., (2007) concluded that the inorganic fertilizers had relatively positive effect on soil enzymes activity than organic fertilizers. Despite of the fact that agrochemicals are important tools in agriculture to minimize the economic losses caused by weeds, insects and pathogens, they are also known to influence various microbial activities in soil (Tejada et al., 2010). In accordance to this study, Tu (1992) from his study concluded that herbicides do not have a drastic effect on soil microbes and enzymatic activities which are important to soil fertility. Among $\mathrm{Bt}$ cotton grown soil treated with different herbicides, Bt cotton with pendimethalin treated soils showed higher DHA because some fungi (Atri et al., 2006) and bacteria (Veena et al., 2010) are able to utilize as a sole source of carbon and indicating that it could be least toxicity compared to other herbicides.

\section{Acidic phosphatase enzyme activity}

High acidic phosphatase activity was recorded in non Bt cotton than the Bt cotton grown soil at all growth stages. When Bt cotton was compared with other Bt cotton with other herbicide treatments, high enzyme activity (29.8 $\mu \mathrm{g}$ p-nitro phenol/g of soil/day) was seen in both Bt cotton and Bt cotton + pendimethalin treated soil at flowering stage. At harvesting stage all the treatments have shown significantly less acidic phosphatase activity than other stages. Significantly lower acidic phosphatase activity $(10.67 \mu \mathrm{g}$ p-nitro phenol/g of soil/day) was found in Bt cotton + pyrithiobac sodium + quizalofop treatment at harvesting stage. Among the three herbicide treatments $\mathrm{Bt}$ cotton + pendimethalin was found to have significantly more activity after Bt cotton in all growth stages (Table 6 and Figure 6).

Acidic phosphatase activity was reported to increase upto the boll formation and decreased towards the harvesting stage (Vandana et al., 2012). More activity in Bt cotton + pendimethalin than the other herbicide treatments might be due to the development of the tolerance in 
microorganisms or increased adaptation towards the herbicides (Sebiomo et al., 2011).

\section{Alkaline phosphatase enzyme activity}

At all the growth stages, non Bt cotton was found to have significantly higher alkaline phosphatase activity when compared with the Bt cotton. Highest activity (44.3 $\mu \mathrm{g}$ p-nitro phenol/g of soil/day) was observed at boll formation stage in non Bt cotton and lowest activity (15 $\mu \mathrm{g}$ p-nitro phenol/g of soil/day) at harvesting stage in $\mathrm{Bt}$ cotton + pyrithiobac sodium + quizalofop treated soil. The enzyme activity was found significantly increasedupto the boll formation stage and decreased at harvesting stage. Among all the treatments the Bt cotton + pyrithiobac sodium + quizalofop has showed significantly lowest enzyme activity at all growth stages (Table 7 and Figure 7).

Activity of the alkaline phosphatase enzymes increased with the age of the crop and decreased towards harvest (Vandana et al., 2013). More activity of enzyme in Bt cotton + Pendimethalin might be due to the development of the tolerance and increased adaptation towards the herbicides by the microbes (Sebiomo et al., 2011). Bt cotton + pyrithiobac sodium + quizalofop showed less activity than other herbicide treatments, which might be due to the sensitivity of the alkaline phosphatase enzyme to the herbicides (Ewa, 2011). In contrast, Kucharski and Jadwiga (2008) reported that the alkaline phosphatase was most tolerant to the herbicides.

\section{Urease enzyme activity}

Urease enzyme activity in all the growth stages was found to have significantly higher in non $\mathrm{Bt}$ cotton when compared with the $\mathrm{Bt}$ cotton. The enzyme activity in Bt cotton soil when compared with Bt cotton with herbicide treatments, Bt cotton + pendimethalin treated soil at flowering state has showed high activity $(2.70 \mu \mathrm{g}$ of ammonia/g of soil $/ \mathrm{h})$ after non- Bt cotton at boll formation and harvesting stage high urease. Among all the treatments significantly low urease activity was found in Bt cotton + pyrithiobac sodium + quizalofop treatment at all growth stages.

The enzyme activity was found to significantly increase up to the boll formation stage and decreased at harvesting stage except in non $\mathrm{Bt}$ cotton where urease activity increased up to the flowering stage and decreased towards the harvesting stage (Table 8 and Figure 8).

The urease enzyme activity was reported to increase with the age of the crop and decreased towards the harvest (Vandana et al., 2013). In contrast to the present study, Ewa (2011) and Kucharski and Jagwiga (2008) reported that urease activity was most sensitive to the herbicides. This study results showed that the urease activity is least affected by herbicides, whereas Baruah and Mishra (1986) found no effect of the herbicide on urease activity.

Significantly more activity of enzyme in treatment $\mathrm{Bt}$ cotton + pendimethalin might be due to the development of the tolerance in microorganism or increased adaptation towards the herbicides (Sebiomo et al., 2011).

Based on the results obtained in the present study, it can be concluded that non Bt cotton sown soils showed higher DHA, alkaline and acidic phosphatases, and urease enzyme activities when compared to the $\mathrm{Bt}$ cotton soils at all growth stages in cotton. The herbicide pendimethalin treatment did not affect the urease, though there were significant decrease in DHA and phosphatase soil enzymes at all growth stages when compared to the Bt cotton 


\section{References}

Anderson, T.H. 2003. Microbial ecophysiological indicators to assess soil quality, Agriculture, Ecosystems and Environment activities in two soils, Australian Journal of Soil Research. 36: 449-456.

Atri, S.B., Jayanta, S., Subhendhu, C., Ashim, C and Narayan, C. 2006. Degradation of Pendimethalin by soil fungi. Pesticide Science. 4(29): 419-425.

Baruah, M and Mishra, R.R. 1986. Effect of herbicide butachlor, 2,4-D and ozyfluorfen on enzyme activities and $\mathrm{CO}_{2}$ evolution in submerged paddy field soil. Plant and Soil.96: 287-291.

Bera, S. and Ghosh, R.K. 2013.Soil Microflora and Weed Management as Influenced by Atrazine $50 \% \mathrm{WP}$ in Sugarcane. Universal Journal of Agricultural Research. 1(2): 41-47.

Bowles T.M., Acosta-Martínez V., Calderón F., Jackson L.E. 2014. Soil enzyme activities, microbial communities, and carbon and nitrogen availability in organic agroecosystems across an intensively-managed agricultural landscape. Soil Biology and Biochemistry. 68: 252-262.

Burns, R.G. 1978. Soil enzymes. Academic Press, London.

Casida, L.E. 1997. Microbial metabolic activity in soil as measured by dehydrogenase determinations. Applied and Environmental Microbiology. 6(34): 630-636.

Chauhan, A.K., Das, A., Kharkwal, H., Kharkwal, A.C. and Varma, A. 2006. Impact of microorganisms on environment and health. Microbes Health and Environment.1-12.

Chu, H., Lin, X., Fujii, T., Morimoto, S., Yagi K., Hu, J. \& Zhang, J. (2007). Soil microbial biomass, dehydrogenase activity, bacterial community structure in response to long-term fertilizer management. Soil Biology and Biochemistry. 39: 2971-2976.

Eivazi, F and Tabatabai, M.A. 1977. Alkaline and acid phosphatases activity in soils. Soil Biology and Biochemistry. 9(3): 167-172.

Ewa, J. 2011. The effect of chloropyriphos and teflubenzuron on the enzymatic activity of soil. Polish Journal of Environmental Study. 20(4): 903-910.

Gu, Y., Wag, P. and Kong, C. 2009. Urease, invertase, dehydrogenase and polyphenoloxidase activities in paddy soils influenced by allelophatic rice variety. European Journal of Soil Biology. 45: 436-441

Hang, M., Ye, Y., Chen, Z., Wu, W and Du, Y. 2001. Effects of butachlor on microbial populations and enzyme activities in paddy soil. Journal of Environmental Science and Health, Part B: Pesticides, Food Contaminants, and Agricultural Wastes 5 (36): 581595.

Jarvan, M., Edesi, L. Adamson, A. Vosa, T. 2014. Soil microbial communities and dehydrogenase activity depending on farming systems. Plant Soil Environment. 60 (10): 459-463.

Kucharski, J and Jadwiga, W. 2008. Biological properties of soil contaminated with herbicide Apyros 75 WG. Journal of Elementology. 13(3): 357-371.

Min, H., Y.F. Ye, Z.Y. Chen, W.X. Wu and Y.F. Du. 2002. Effects of butachlor on microbial enzyme activities in paddy soil. Journal Environmental Science. 14: 413-417.

Munoz-Leoz, B., Ruiz-Romera, E., Antiguedad, I. and Garbisu, C. 2011. Tebuconazole application decreases soil microbial biomass and activity. Soil Biology and Biochemistry. 43: 21762183. 
Nada, A., Milosevia and Mitar, M.G. 2002. Effect of herbicides on microbiological properties of soil. Proceedings of Natural Sciences. 102: 5-21.

Nannipieri, P., J. Ascher, M. T. Ceccherini, L. Landi, G. Pietramellara and G. Renella, 2003. Microbial diversity and soil functions. European Journal of Soil Science.54: 816-824.

Nunan, N., Morgan, M.A., Heriihy, M. 1998. Ultraviolet absorbance $(280 \mathrm{~nm})$ of compounds released from soil during chloroform fumigation as an estimate of the microbial biomass. Soil Biology and Biochemistry.30: 1599-1603.

Saeki, M and K. Toyota. 2004. Effects of bensulfuron- methyl on the soil bacterial community of paddy soil microcosm. Boil. Fertil.Soil.40: 110118.

Sebiomo, A., V.W. Ogundero, and S.A. Bankole. 2011. Effect of four herbicides on microbial populations, soil organic matter and dehydrogenase activity. African Journal of Biotechnology. 10(5): 770-778.

Tabatabai, M.A and Bremner, J.M. 1969. Assay of urease activity in soils. Soil Biology Biochemistry. 4: 479-48.
Tejada, M., Garcia-Martinez, A., Gomez, I. and Parrado, J. 2010. Application of MCPA herbicide on soils amended with biostimulants: short-time effects on soil biological properties. Chemosphere. 80:1088-1094.

Tu. C.M. 1992. Effect of some herbicides on activities of microorganisms and enzymes in soil. Journal of Environmental Science and Health, Part B: Pesticides, Food contaminants, and Agricultural Wastes. 6(27): 695709

Vandana, L. J., P.C. Rao and G. Padmaja. 2012. Effect of herbicides and nutrient management on soil enzyme activity. Journal of Rice Research.5: 50-56.

Veena, B.M., Preethi, N.T., Robertcyril, S.H., Sikandar, I.M and Harichandra, Z.N. 2010. Degradation of Pendimethalin by Bacillus circulans. Indian Journal of Biotechnology. 9:173-177.

Xiaogang, Biao, L., Jinjie, C., Doudou, L., Shuai, D., Ben, G., Junyu, L., Zhixinang, F., Wei, C and Zhengmin, H. 2011. No evidence of persistent effects of continuously planted transgenic insects-resistant cotton on soil microorganisms. Plant Soil. 399:247-257.

\section{How to cite this article:}

Tejashree, M., R. Subhash Reddy and Anuradha, G. 2018. Effect of Herbicides on Microbial Population and Soil Enzymes in Bt Cotton Cultivated Soils. Int.J.Curr.Microbiol.App.Sci. 7(09): 3240-3255. doi: https://doi.org/10.20546/ijcmas.2018.709.403 